\title{
Appraisal Perspective on Attitudinal Analysis of Public Service Advertising Discourse
}

\author{
Hai-bin $\mathrm{Wu}^{1}$ \\ ${ }^{1}$ Guangdong Polytechnic College, Guangzhou, China \\ Correspondence: Hai-bin Wu, Guangdong Polytechnic College, 510520, Guangzhou, China. Tel: \\ 86-186-2068-0360. E-mail: haibinwu@126.com \\ Received: January 4, 2013 Accepted: January 23, 2013 Online Published: January 29, 2013 \\ doi:10.5539/ells.v3n1p55 URL: http://dx.doi.org/10.5539/ells.v3n1p55
}

\begin{abstract}
This article aims to analyze the attitudinal meaning of public service advertising discourse using the Appraisal Framework with a view to revealing how linguistic elements realizes the appraisal meaning and especially what attitudinal value is of frequent occurrence in the target discourse. Through the analysis and study, this article will come to the conclusion that in the attitude system, affect turns to be the least presentation; implicit judgment shows less distribution than explicit judgment; and more judgment occur rather than affect and appreciation.
\end{abstract}

Keywords: Appraisal Framework, attitudinal meaning, affect, judgment, appreciation

\section{Introduction}

Language can be used to express the writer's/speaker's opinion on people, things and situations. There exist opinion-related meanings in language as resources of evaluation or appraisal in language. As one kind of appraisal resources, attitude plays an important role in the expression of interpersonal meanings of language. Attitude refers to a way that you behave towards someone or in a particular situation, especially when this shows how you feel. In Appraisal Framework, as is proposed by Martin and his colleagues, Attitude refers to values by which speakers pass judgments and associate emotional/affectual responses with participants and processes (White, 2001). Attitude, alongside with Engagement and Graduation, constitutes the Appraisal Framework in language. Appraisal Framework is a particular approach to exploring, describing and explaining the way language is used to evaluate, adopt stance, construct textual persona and arrange interpersonal positions and relationships. Attitude in the present article is a label used to cover all the attitudinal meanings in the Appraisal Framework. For example:
a) I love Mary very much.
b) He is a brave soldier.
c) What a beautiful picture.

"Love" in sentence a) is a word that carries emotional attitude towards "Mary"; "brave" in sentence b) carries value judgment according to some social norms; "beautiful" in sentence c) carries esthetical attitude towards the "picture", and all these attitudinal meanings are put under the category of Attitude in Appraisal Framework. Within the Appraisal Framework, Attitude itself is divided into three sub-systems, i.e. Affect, Judgment and Appreciation, with Affect referring to the characterization of phenomena by reference to emotion, Judgment the evaluation of human behavior with respect to social norms and Appreciation the evaluation of objects and products (rather than human behavior) by reference to aesthetic principles and other systems of social value (White, 2001).

Appraisal Framework is an analytical approach to explore, describe and explain the ways a language is used to evaluate, adopt stances, construct textual personas and manage interpersonal positioning and relationships. Thus it explores how speakers/writers pass judgments on other speakers/writers, their utterances, material objects, happenings and states of affairs, and thereby form alliances with those who share these views and distance themselves from those who do not. It explores how attitudes, judgments and emotive responses are explicitly presented in texts and how they may be more indirectly implied, presupposed or assumed. Besides, it explores how expressions of such attitudes and judgments are, in many instances, carefully managed so as to take into account the ever-present possibility of challenge or contradiction from those who hold differing views. In sum, 
Appraisal Framework is a system of interpersonal meanings. Speakers/writers use the resources of Appraisal to negotiate their social relationships, by telling their listeners/readers how they feel about things and people, in other words, what their attitudes are.

Appraisal Framework provides an analytical tool for us to better understand the issues associated with evaluative language and with the negotiation of intersubjective positions. Being comprehensive and discourse-based, it works well in answering the following questions (White, 2001):

a) What are the speakers or writers' evaluative strategies by which they present themselves? For example, more or less deferential, dominating, authoritative, inexpert, cautious, conciliatory, emotional, impersonal and so on.

b) How the different uses of evaluative language by speakers or writers act to construct different authorial voices and textual personas.

c) How different genres and text types may employ different evaluative strategies accordingly.

d) What are the underlying social value and belief systems which shape the speaker or writer's utterances?

e) How different modes of story-telling can be characterized by their different uses of the resources of evaluation.

\section{Related Literature}

The Appraisal Framework has grown out of the functional perspective in linguistics. As we know, functional grammar perceives language as having three metafunctions, namely, ideational, interpersonal and textual. The interpersonal metafunction is concerned with interaction between the addresser and addressee in the discourse situation and with the addresser's attitude toward what he speaks or writes about. Halliday pinpoints mood, modality and key as major exponents of interpersonal meaning. In his Introduction to Functional Grammar, he mentioned the existence of other means of realizing IP meaning. But even these cannot be exhaustive. By emphasizing the semantics of evaluation, the Appraisal Framework has opened up a new area of IP meanings. In this framework, Martin discusses the evaluation system in language communication, i.e. how to use language to express emotion, ethics and aesthetic value.

This appraisal model is multidimentional, incorporating 3 kinds of semantic resources. Attitude, the expression of feelings, Engagement, the sourcing of attitudes and negotiation of heteroglossic diversity and Graduation, the scaling of interpersonal force or for sharpening/blurring the focus of valuer relationships. Each system has its own sub-systems for the writer or speaker to make semantic choices. The outline of the Appraisal Framework is presented in Table 1 (from Martin and White, 2005:38).

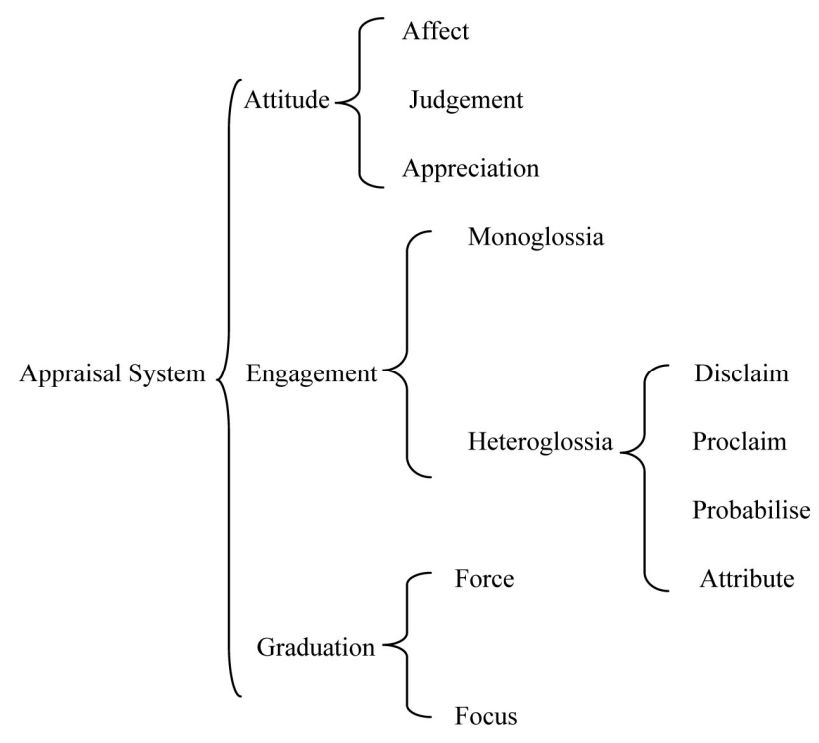

Figure 1. An Overview of Appraisal Framework 


\section{Methodology}

There has been a rapidly growing interest of researches into the functioning of specific grammatical resources for interpersonal meaning. Considering the tremendous variety of text types that constitute public adverting discourse, research on its appraisal system or attitudinal analysis of the discourse has been surprisingly inadequate.

Under the three systems of Appraisal Framework, attention will be mainly paid to the application of attitude, which also encompasses three categories: affect, judgment and appreciation. Little attention will be paid to engagement and graduation in this article.

The three categories of affect, judgment and appreciation belong respectively to psychology and emotional world, ethics and human behavior and nonhuman behavior. Since advertising appeals more to psychology than to ethics and features human rather than nonhuman behavior.

Both qualitative and quantitative analytical techniques are adopted in this study. Firstly, it will explore the linguistic elements that may realize attitudinal values; secondly, the evaluation of elements will be collected and presented in the form of tables; thirdly, these elements will be analyzed and evaluated to see how they contribute to the conveyance of attitudinal position in the samples. Through the analysis, it is hoped that those interpersonal features in samples could be summarized to support or query the hypothesis.

\section{Findings and Discussions}

As mentioned in the former section, the three subsystems - Affect, Judgment, and Appreciation are under the system of Attitude in Appraisal Framework. Five examples are extracted from Theory and Practice of Discourse Analysis: A Study in Advertising Discourse by HUANG Guowen. After researching five samples in the Appraisal Framework, the total number of attitudinal meanings in the five samples is 60 . The detail numbers of each sample are 11, 12, 9, 8 and 20. The number of affectual values in five samples is 9 . That of judgment is 32 and appreciation 19. The detail distributions of the three-attitudinal values are shown in the following tables. And table 4.5 is the percentage distribution of attitudinal meanings in the five samples.

Table 1. Statistics of Affect

\begin{tabular}{|c|c|c|c|c|}
\hline & \multicolumn{3}{|l|}{ Affect } & \multirow{2}{*}{$\begin{array}{l}\text { Total number of } \\
\text { Attitude in the } \\
\text { samples }\end{array}$} \\
\hline & Quality & Process & Comment & \\
\hline \multirow{2}{*}{ Sample 1} & 0 (positive) & 1(positive) & 0 (positive) & \multirow{2}{*}{11} \\
\hline & 0 (negative) & 0 (negative) & 1(negative) & \\
\hline \multirow{2}{*}{ Sample 2} & 0 (positive) & $0($ positive $)$ & 0 (positive) & \multirow{2}{*}{12} \\
\hline & 0 (negative) & 1(negative) & 0 (negative) & \\
\hline \multirow{2}{*}{ Sample 3} & 0 (positive) & 0 (positive) & 1(positive) & \multirow{2}{*}{8} \\
\hline & 2(negative) & 0(negative) & 0 (negative) & \\
\hline \multirow{2}{*}{ Sample 4} & 0 (positive) & 0 (positive) & 0 (positive) & \multirow{2}{*}{9} \\
\hline & 0 (negative) & 0 (negative) & 0 (negative) & \\
\hline \multirow{2}{*}{ Sample 5} & 0 (positive) & 2 (positive) & 1(positive) & \multirow{2}{*}{20} \\
\hline & 0 (negative) & 0 (negative) & 0 (negative) & \\
\hline Total number & 2 & 4 & 3 & 60 \\
\hline
\end{tabular}

As shown by Table 1, the distributions of affect in the five samples are in a fairly little amount; in sample four, no affect is revealed. Another noticeable fact is that most affect values from the five samples belong to the process.

Table 2. Distribution of Social Esteem and Social Sanction Judgment

\begin{tabular}{llllll}
\hline & \multicolumn{2}{l}{ Judgment } & & \multirow{2}{*}{ Total number of Attitude } \\
\cline { 2 - 5 } & Social esteem & \multicolumn{2}{l}{ Social sanction } & in the samples \\
\cline { 2 - 5 } & Positive & Negative & Positive & Negative & \\
\hline Sample 1 & 5 & 2 & 0 & 0 & 11 \\
\hline Sample 2 & 3 & 3 & 1 & 0 & 9 \\
\hline Sample 3 & 3 & 0 & 0 & 0 & 8 \\
\hline Sample 4 & 3 & 1 & 0 & 1 & 20 \\
\hline Sample 5 & 4 & 5 & 0 & 1 & 60 \\
\hline Total & 18 & 11 & 1 & 2 & \\
\hline
\end{tabular}


Table 2 is the distribution of social esteem and sanction judgment in five samples. There are totally 32 judgments--29 social esteem judgments and 3 social sanction judgments. First, more social esteem judgment occurs than social sanction judgment. Second, little social sanction judgment has been reflected in the samples. Third, the numbers of positive and negative judgment tend to be evenly distribution in the samples.

Table 3. Distribution of Explicit and Implicit Judgment

\begin{tabular}{llllll}
\hline & Judgment & & & $\begin{array}{l}\text { Total number } \\
\text { of Attitude in } \\
\end{array}$ \\
\cline { 2 - 6 } & Explicit & & Implicit & & 11 \\
\hline Positive & Negative & Positive & Negative & 12 \\
\hline Sample 1 & 5 & 1 & 0 & 1 & 9 \\
\hline Sample 2 & 4 & 2 & 0 & 0 & 8 \\
\hline Sample 3 & 3 & 0 & 0 & 0 & 20 \\
\hline Sample 4 & 3 & 2 & 0 & 0 & 60 \\
\hline Total 5 & 4 & 6 & 0 & 2 & 1 \\
\hline
\end{tabular}

It is obviously that explicit judgment value is the dominant kind of attitude compared with the implicit judgment with the rate of 30:2. The numbers of positive and negative judgment are distributing in the sample evenly. And the number of explicit positive judgment ranks first in all the judgment values. Totally, there are 19 positive explicit judgments, 11 negative explicit judgments, 0 positive implicit judgments, and 2 negative implicit judgments. Sample 3, 4 and 5 have no other implicit judgments except explicit ones.

Table 4. The Distribution of Appreciation

\begin{tabular}{llll}
\hline & Appreciation & Total number of \\
\cline { 2 - 4 } & Positive & Negative & $\begin{array}{c}\text { Attitude in the } \\
\text { samples }\end{array}$ \\
\hline Sample 1 & 2 & 0 & 11 \\
\hline Sample 2 & 2 & 2 & 12 \\
\hline Sample 3 & 1 & 2 & 9 \\
\hline Sample 4 & 2 & 1 & 8 \\
\hline Sample 5 & 2 & 5 & 20 \\
\hline Total & 9 & 10 & 60 \\
\hline
\end{tabular}

According to Table 4, it is obviously that the number of positive appreciation and negative appreciation are evenly presented in the samples with the rate of 9:10. Except sample 1, almost every sample reveals positive and negative appreciation. It means that positive aesthetic words or expressions are distributed in the samples.

Table 5. The Percentage Distribution of Attitude in the Five Samples

\begin{tabular}{llll}
\hline & $\begin{array}{l}\text { Distribution of Affect } \\
\text { in the sample }\end{array}$ & $\begin{array}{l}\text { Distribution } \\
\text { Judgment in the sample }\end{array}$ & $\begin{array}{l}\text { Distribution } \\
\text { Appreciation } \\
\text { sample }\end{array}$ \\
\hline Sample 1 & $18 \%$ & $64 \%$ & $\begin{array}{c}\text { of } \\
\text { the }\end{array}$ \\
\hline Sample 2 & $8 \%$ & $58 \%$ & $34 \%$ \\
\hline Sample 3 & $33 \%$ & $34 \%$ & $33 \%$ \\
\hline Sample 4 & 0 & $67 \%$ & $33 \%$ \\
\hline Sample 5 & $15 \%$ & $50 \%$ & $35 \%$ \\
\hline
\end{tabular}

The results of attitude distribution showed in Table 5 turn out to be different from the hypothesis that more affect of the attitude system occurs in public service advertising discourse than affect and appreciation. However, the analysis and calculation have shown that more attitudinal values occurring in the categories of judgment rather than affect and appreciation. More details of data analysis will be interpreted in the next section.

The five tables have shown the distribution and feature of attitude in public service advertising discourse; this part will present more detail text analysis of the samples. Though the analysis of the selected samples, it is hoped 
that the encoded attitudes and potential features of public service advertising discourse could be explored. Before proceeding any further, it is important to state the personal position in relation to these samples. The attitude toward public service advertising discourse presented is neutral. The sentences that contained attitudinal meanings are numbered for the convenience of analyzing. The values of affect, judgment and appreciation are in italics and bold.

\subsection{The Analysis of Affect}

As the first system of attitude, affect is indicated mainly through verbs of emotion and concerned with the appraiser's emotional states. That is, an author can express attitude towards some phenomenon by indicating how that phenomenon affected them emotionally and appraising something in affectual terms. Affect occurs as either positive or negative categories. It is composed by three subsystems "quality", "process", and "comment". The following part will explain and analyze in detail the attitude expressions sampled in Table 1.

1. By the time you read this, we hope these children will have the help they so desperately need. Sample one is concerning the worldwide notice about the children living under poverty and disease. "Hope" here is positive affect. The appraiser is the public service advertising writer; actually, it refers to the world. It is "process" in affect, which means that the advertising uses process lexicons to express its feeling. It is mainly mental and behavioral to reveal the mental affective meaning and behavioral affective meaning. The advertising expresses its attitude by appraising the attitude of the world in the child issue.

"Desperately need" is the negative "comment" affect in the sample. It is used to comment on the feeling of those children, who express their negative attitude towards the effort that people in the world took, but they show negative feeling on the result.

2. Frail and alone, she recently had to give up her work because of failing health.

"Alone" is negative affect, and the evaluated is Nziku. It belongs to "behavioral process". The reason that Nziku lives alone is that she has no family, no relatives and even no friends. It has revealed the surge of Nziku's emotion. The appraised is the feeling of Nziku. She is desperately in need of your concern. Without your help, she can never pick up her life any longer.

\section{3. "Homeless"}

"Homeless" is negative affect. The evaluated is the animals. It is a "quality" affect. The word "homeless" reveals the condition of the animals. It is presented in negative affect. It reveals the negative feeling of the appraised, which can be changed by the public. It is human beings who reject them.

4. Hopefully, by the time you read this ad, this little fellow will have found a good home.

"Hopefully" is the positive "comment" affect in the sample. It is a quality adverb used as an interpersonal theme to express the feeling of public service advertising writer, who expresses his positive attitude towards the effort that the people who read the ad took to rescue the animals.

5. He's one of the thousands of friendly, companion animals, (both pure breed and cross breed) who have been made homeless by the increasing demands of Estate Managements which are forcing dog-owners to get rid of their pets or lose their flats.

"Homeless" here is also negative affect. The appraised is the deserted animals. It is "quality" affect, which reveals the emotion of human beings, which directs at target, the deserted animals. In this case, it is the Estate Managements who force the dog-owners to dispose pets. The owners have to do so, or they will lose their flats.

6. Our staff members willingly risk their lives to restore children's hopes and dreams because we believe that children have a right to be children, to be cared for, to be loved and protected.

"Willingly" is the positive "comment" affect in the sample. It is a quality adverb used as an interpersonal theme to comment on the feeling of the stall members who work in World Vision, a Christian humanitarian organization dedicated to working with children, families and their communities worldwide. This expresses their positive attitude towards the effort they took to rescue the children.

"Be cared for" and "be loved by" all are positive affect, which belongs to the "behavioral process". The appraised is the children in need of help. No matter what happens to the world, children and women should be cared and loved.

According to Table 5, the percentages of the affect in the five samples are: $18 \%, 8 \%, 33 \%, 0$, and $15 \%$ respectively. The instances of affect in the five samples are far outnumbered by appreciation and judgment. 
The following might be the reasons. First, affect is concerned with the appraiser's emotional status. By including more expressions of attitude encoded as affect, the writer constructs a more personalized expression of evaluation. However, the fact is that the public service advertising discourses are usually arguments about or explanations of major events. The heavy application of affectual resources will make the text too personalized and improper for the kind of topic, therefore less persuasive. Second, the subjects of the public service advertising discourses determine the choice among language resources. The big events, issues are related to nations, the public or the nature. There will be fewer opportunities to use too personal affectual words.

When considering the values of affect, the following aspects should be examined. First, do the values of affect come from the external source or from the author? Generally authorial affect involves the writer/speaker indicating how he/she has responded emotionally to the person, thing, happening or situation being evaluated. It is an entirely personalized and individualized mode of evaluation. It provides a means by which an author operating from one socio-semiotic position may negotiate with a reader/listener operating from a different social position; and may establish a point of commonality despite ideological/cultural differences with a reader/listener of a different social position. By appraising events in affectual terms, the speaker/writer invite their audience to share emotional response, or at least to see that response as appropriate and well motivated, or at least as understandable. Naturally, an emotionally sympathetic reader is more likely to concur with the author's evaluative position.

The second concern is whether the attributed evaluator acts as a deputy of the author. That is to say, the author indicates a positive assessment by having some reported source respond with positive emotions to the phenomenon under consideration, or alternatively, the author indicates a negative assessment by having some reported source response with a negative emotion. But it depends on how reliable or reasonable the reported source is.

\subsection{The Analysis of Judgment}

Judgment refers to attitudinal evaluation in which human behavior is negatively or positively assessed by some set of social norms, which include rules, conventions, social acceptability or expectations and systems of value. Author's social position and ethics can be revealed by their judging behaviors in the samples. Difference exists between social esteem and social sanction. The former is categories of normality, capacity and tenacity, and the latter is categories of veracity and propriety. The following part will explain and analyze the attitude expressions sampled in Table 4-2 and Table4-3 in details.

\section{The children you see here are different from ours.}

This sentence is an explicitly negative social esteem judgment; the appraised is the children in poverty and disease. It belongs to "normality", and the description of the children there stirs the peaceful mind of the people who read the ad..

\section{But you can help change all this.}

It is an explicitly positive social esteem judgment, and evaluates the capacity of the people who read the ad, and arouses their attention to the charity activity.

\section{By becoming a sponsor through Christian Children's Fund.}

The sentence is an explicitly positive social esteem judgment; it belongs to the "capacity". It targets at prospective donors. Christian Children's Fund will be the organization that receives the donation.

4. For just £12 (IR £14) a month, you can help give a needy child food.

The sentence contains one explicit judgment and one implicitly judgment. Obviously, "can" is the explicitly positive social esteem judgment, "capacity". The appraised is the people who read the ad. "Needy" is a token of implicitly negative judgment. It belongs to "normality". That is, food is far from enough for the children to survive or live better.

\section{CCF will send your sponsored child's photograph and family background.}

The sentence is explicitly positive esteem judgment, "capacity". The appraised is CCF, the organization. If you sponsor a child, the organization will send you the related information about the child.

\section{By the time you read this, we hope these children will have the help they so desperately need.}

The sentence is explicitly positive social esteem judgment, also falls into the category of "capacity". The evaluated is the children who accept the donation. 


\section{For Nziku, life is harsh.}

The sentence is implicitly negative social esteem judgment, "normality ". Superficially, "is" is a positive token of judgment, but what is expressed in this sentence is that the life for Nziku is not good. Therefore, the meaning is not inscribed but implicit.

8. Frail and alone, she recently had to give up her work because of failing health.

The sampled in italicized phrase is an explicitly negative social esteem judgment; it presents "tenacity". Nziku's "frail" and "failing" health has made work impossible.

9. With no family to look after her, and no money, Nziku can't afford the medicines she needs, or even a proper meal.

That Nziku does not have enough money for medicine is explicitly negative social esteem judgment; it belongs to "capacity". "A proper meal" is explicitly positive social sanction judgment, "propriety".

10. Yet for just over $£ 2$ a week, you can change all this.

"You can change all this" is explicitly positive social esteem judgment, "capacity". The appraised is the advertisement readers or the public.

11. By sponsoring someone like Nziku you can buy her the basics of life, such as food, medicines and clothing.

The sentence is explicitly positive social esteem judgment, "capacity". The evaluated is also the public. They have the capacity to buy the necessaries for the people like Nziku.

12. What's more, your money will support other vital projects to improve life for entire communities.

The sentence is explicitly positive social esteem judgment, "capacity". The appraised is donator's money. Their donated money can help thousands of people in need.

13. Hopefully, by the time you read this ad, this little fellow will have found a good home.

"Will have found" is explicitly positive social esteem judgment, "capacity". The appraised is Nziku and people like her. "Good home" is explicitly positive social esteem judgment, "propriety". The appraised is home.

14. He's one of the thousands of friendly, companion animals, (both pure breed and cross breed) who have been made homeless by the increasing demands of Estate Managements which are forcing dog-owners to get rid of their pets or lose their flats.

The sentence is explicitly positive social esteem judgment; the appraised is the animals. "He" here generally refers to all the homeless but friendly animals.

15. Emerging from the Terminal 396 at 1 am and thinking it's incredibly funny to engage in a bit of shouting and singing.

The sentence is explicitly negative social sanction judgment, "veracity". The appraised is university students' the improper behavior after being drunk. It is really indecent for university students to shout and sing at midnight, disturbing the neighborhood.

16. Well, it's not funny.

The sentence is an explicitly negative social esteem judgment, and the evaluated is the university students' improper behavior.

17. Especially if you are a local resident.

"Especially" is an explicitly positive social esteem judgment, "normality". The appraised is the local resident. "Are" is an explicitly positive social esteem judgment. The appraised is the students who are shouting and singing at midnight when they are drunk.

18. So, be a part of solution, not the problem, keep it down when you leave the Union.

The sentence is explicitly positive social esteem judgment. The appraised is the solution that the university union put forward to address the problem, which is keeping your noises down when you leave the Union.

\section{War today is different.}

The sentence is explicitly negative social esteem judgment, and it belongs to "normality". War today is not the one in the old time, schools and hospitals are attacked as strategic targets.

20. School and hospital communities are attacked as strategic targets children died. Children suffered. 
The sentence is explicitly negative social esteem judgment, and the appraised is the children.

21. Civilian casualties now account for a staggering $90 \%$ of the total, representing a complete turnaround from the world wars when $90 \%$ of the casualties were soldiers.

The sentence is an explicitly positive social esteem judgment. The appraised is the casualty.

\section{Those children who survive the madness around them are left brutalized in mind and body.}

"Madness" is explicitly negative social esteem judgment. The evaluated is the violent battles that besiege children. "Brutalized" is an explicitly negative social sanction judgment, "propriety". The appraised is the mind and body of the children who, though survived the war, are twisted by its madness.

\section{And while the world doesn't object, it won't end.}

"Doesn't object" is explicitly negative social esteem judgment; the evaluated is the world. "Won't end" is explicitly negative social esteem judgment; the appraised is the destruction caused by war, which obviously has not received enough attention.

24. World Vision is at work in most of these nations - places such as Rwanda, Angola, Ethiopia, Mozambique, Somalia, Sudan, Cambodia, Haiti and Bosnia.

The sentence is explicitly positive social esteem judgment; the appraised is World Vision.

25. Our staff members willingly risk their lives to restore children's hopes and dreams because we believe that children have a right to be children, to be cared for, to be loved and protected.

The sentence is explicitly positive social esteem judgment. The appraised is the children. Children have the right to live and play. Nothing could violate the norm.

26. But if they remain out of sight and out of mind, our best efforts will fall far short of their needs.

The sentence is explicitly positive social judgment. The evaluated is the effort of the staff members of World Vision.

Table 5 shows that the percentages of judgment in the five samples are: $64 \%, 58 \%, 34 \%, 67 \%$, and $50 \%$. There are totally 32 judgments-- 29 social esteem judgments and 3 social sanction judgments.

According to the percentages in Table 2, social esteem and social sanction are not evenly distributed, and more judgment values are used in the public service advertising discourse than the affect values. The number of social sanction judgment ranks second in the judgment values in the five samples, much lower than social esteem.

As we mentioned in the previous section, while social esteem involves admiration and criticism, typically without legal implications, social sanction on the other hand involves praise, and condemnation, often with legal implications. The most commonly used judgment value in the samples is the social esteem judgment. The overwhelming use of social esteem might be explained by desired neutrality and objectivity of public service advertising discourse; public service advertising discourse tends to place greater emphasis on the information-conveying function, which is primarily concerned with facts and truth-values.

And among the judgment value in social esteem, capacity ranks the first among the three categories. It is due to the feature of public service advertising discourse; it calls on people to do or not to do.

The numbers of positive and negative social esteem may be determined by the content of the public service advertising discourse. Sample three is about the stardust mission returning to the earth.

As shown in Table 3, explicit judgment value is the dominant kind of attitude compared with the implicit judgment with the rate of 30:2. The numbers of positive and negative judgment are evenly distributed in the text. And the number of explicit positive judgment ranks first in all the judgment values. It may be determined by the information-conveying function of public service advertising discourse. Without pictures and images in most public service advertising discourse, facts and truth-values have to be illustrated in explicit words in order to present the message more clearly to the audience/readers. Therefore, there is little need to express the potential meaning in implicit judgment.

\subsection{Analysis of Appreciation}

Appreciation contains values, which express both aesthetic and non-aesthetic categories of social valuation, and it includes meanings such as significance and harmfulness. It evaluates natural objects, manufactured objects, as well as more abstract texts such as plans and policies. Appreciation can be divided into positive and negative values. The following part will explain and analyze the attitude expressions sampled in Table 4 in detail. 


\section{Clothing. Medical care. Or whatever is needed most.}

"Most" is positive appreciation. It belongs to "valuation", attributed to "whatever". It seems that everything you name, the children are in need of.

\section{But there are so many more waiting.}

"Many more" is positive appreciation, it belongs to "composition". The appraised is the children living under poverty and disease. Even if you give out your money or donation, it is too little to meet the demand.

\section{For Nziku, life is harsh.}

"Harsh" is negative appreciation, it belongs to "reaction". The appraised is Nziku's life. It seems that God doesn't treat her justly. Sympathetic with Nziku, the advertising writer tries to arouse public concern.

4. Frail and alone, she recently had to give up her work because of failing health.

"Failing" is negative appreciation, and it belongs to "reaction". The appraised is Nziku's health. Her condition is so bad that she can't even go to work and earn herself butter and bread.

5. What's more, your money will support other vital projects to improve life for entire communities.

"Vital" is positive appreciation, "valuation". The evaluated is the project to improve life for the community. It seems that the project is very important for them. "Entire" is positive appreciation, and it belongs to "composition". The appraised is the community.

6. Hopefully, by the time you read this ad, this little fellow will have found a good home.

The adjective "little", here as a reaction, conveys a negative appreciation of the pitiful animals whom you might help found a home.

7. He's one of the thousands of friendly, companion animals, (both pure breed and cross breed) who have been made homeless by the increasing demands of Estate Managements which are forcing dog-owners to get rid of their pets or lose their flats.

Animals being the appraised, the positive appreciation "friendly" is used to prompt people to adopt them, while the negative appreciation "increasing", is used as an interpersonal theme to suggest the demands are to blame for the animals' distress.

8. Emerging from the Terminal 396 at 1 am and thinking it's incredibly funny to engage in a bit of shouting and singing.

"Funny" is positive appreciation, "reaction". The appraised is to shout and sing. Actually, with a negative judgment before head, here "funny" is not funny. "A bit of" is negative appreciation, "composition". The appraised is shouting and singing, and the noise made by the university students. It is ironical, it is really improper to make nay noise at midnight.

9. Well, it's not funny.

"Funny" is also positive appreciation, "reaction", and the appraised is also the noise mentioned above.

10. Civilian casualties now account for a staggering $90 \%$ of the total, representing a complete turnaround from the world wars when $90 \%$ of the casualties were soldiers.

"Staggering" is negative appreciation, "reaction". The appraised is the number of the civilian casualties; shockingly, civilians become the target of attack. "Complete" is negative appreciation, "composition". The evaluated is the trend of war.

\section{The death of trust may be their heaviest loss.}

"Heaviest" is negative appreciation, "valuation". The appraised is the loss of the children in war. They totally lose their dreams and hopes.

12. World Vision is at work in most of these nations - places such as Rwanda, Angola, Ethiopia, Mozambique, Somalia, Sudan, Cambodia, Haiti and Bosnia.

"Most" is positive appreciation, "composition". The appraised is the nations in which the World Vision carries out their obligations. It tells us that the organization is world-widely operating.

13. But if they remain out of sight and out of mind, our best efforts will fall far short of their needs.

"Best" is positive appreciation, and it belongs to "valuation". The appraised is the efforts of the World Vision.

What is illustrated by Table 4 is that positive appreciations and negative appreciations are presented evenly in 
numbers. This may be determined by the appraised. If the appraised is the subject that the public service advertising discourse tries to provoke, negative appreciation is probably applied. On the country, if the appraised is the reader or the exterior force which dose good or has positive meaning to the subject mentioned in the advertising, positive appreciation is preferable.

According to Table 4.5, the appreciation values play an important role in the attitude system. In most of the samples, it takes a third of the percentages. The feature of public service advertising discourse, which has no pictures, in most cases, might determine it. Listener/reader cannot perceive an image directly. Therefore, the public service advertising discourse has to express the content in some aesthetic or non-aesthetic attitude so that listener/ reader could be impressed deeply. As a consequence, it presents a lot attitude in the values of appreciation.

The attitudinal analysis of the five samples has presented that the interpersonal meaning of the public service advertising discourse is mainly conveyed on the lexical layer for showing more vivid pictures to the audience/reader. It is hoped that more attitudinal meaning will be found through analyzing the tables drawing from the five samples.

\section{Conclusions and Limitations}

\subsection{Main Findings}

After attitudinal analysis of the public service advertising discourse and statistic analysis of the attitudes in the samples, there are totally 6 findings in the article.

First, the results of attitude distribution contradict our initial hypothesis that in public service advertising discourse more attitudes occur in the category of affect rather than judgment and appreciation. However, the analysis and calculation have shown that more attitudinal values occur in the categories of judgment rather than affect and appreciation, which points to public service advertising discourse's concern with human behavior and the objective world rather than with the emotional field. Since events are transmitted, through media that is public service advertising discourse itself, by the means of word depiction. It might be a feasible method to present more nonhuman behavioral expressions so as to present the listeners/readers with a vivid mental image, through which information is more easily received and transformed into action.

Second, the distributions of affect in the ten samples are substantially outnumbered by judgment and appreciation, which means little psychology, feeling and emotions are presented. It shows the objectivity of the public service advertising discourse.

Third, most affect values in public service advertising discourses are process. That is, the public service advertising discourse usually uses process lexicon to express the attitude, and seldom uses quality words. It might present clearer and more continuous information to the listeners/readers, and decline the writer's emotional words.

Fourth, more social esteem judgments occur than social sanction judgment. Little social sanction judgment has been found in the samples. The overwhelming use of social esteem demonstrates the neutrality and objectivity of the public service advertising discourse, which is mainly associated with capacity. It seldom concerns the veracity and propriety of the subject in the advertising. This is because the information should be objective, and common people who come across the advertising have the capacity to follow the information transmitted and take their actions.

Fifth, the explicit judgment is the most commonly used in judgment, which means the public service advertising discourse often use more direct or vivid expression to inform, so as to make up the shortcoming of lacking of pictures.

Finally, positive and negative appreciations are presented evenly. That is to say, the use of the attitudinal meaning in appreciation is determined by the appraised. If the appraised is the subject that the public service advertising discourse tries to inform, negative appreciation is probably applied. On the country, if the appraised is the reader or the exterior force which dose good or has positive meaning to the subject mentioned in the advertising, positive appreciation is preferable.

\subsection{Significance of the Research}

First, appraisal is a topic worthy of study. The expression of the writer's or speaker's opinion is an important feature of language. Following SFL, this article takes the language user's perspective. 
Second, the investigation may provide insights into English language teaching in China. The investigation of interpersonal meaning of the public service advertising discourse is significant in the sense that it can be used in the advertising discourse reading and teaching. Listeners/readers can understand this kind of discourse effectively.

Chinese culture holds the Doctrine of the Mean, so the way people express their attitudes in the related advertising discourse will definitely be different from that of the western people. Peng Xuanwei (2000: 128) views that there are much less comment adjuncts in the Chinese language. Therefore, when teaching the English language, it will be very important to predict the difficulties that students may meet when constructing their appraisal system in the English language. The analysis in this article may be helpful in doing the prediction.

Third, the characteristics of the public service advertising discourse discovered here will provide a helpful guide in trans-cultural communication. The analysis will help us understand the English appraisal system in the public service advertising discourse. If we get to know more about the English appraisal system, we can understand western cultures, customs and ideas better, then we can make ourselves less misunderstood, and at the same time we can understand the English language better.

\subsection{Limitations}

This article is by no means a general analysis of the appraisal meaning of public service advertising discourse. It has its limitations. First, little engagement and graduation systems in the Appraisal Framework have been touched upon. Second, because of the imperfection of the Appraisal Framework itself, it is possible that some linguistic elements that provoke the attitudinal meaning in public service advertising discourse may be overlooked. Third, this study has tried to avoid being subjective in analyzing. As the appraisal system is closely concerned with the ideological and cultural values, it is impossible to be fully objective in the attitudinal analysis. Though there may remain mistakes in the dissertation, it is hoped that the study is somewhat worthwhile.

\section{References}

Cai, H. (2005). A Study of Commentary Pragmatic Markers in English Advertising Discourse-An Appraisal Approach. Journal of PLA University of Foreign Languages, 2, 6-11.

Cook, G. (1992). The Discourse of Advertising. London: Routledge and Kegan Paul.

Eggins, S. (1994). An Introduction to Systemic Functional Linguistics. London: Cassell.

Halliday, M. A. K. (1994). An Introduction to Functional Grammar. London: Edward Arnold.

Huang, G. W. (2001). Theory and Practice of Discourse Analysis: A Study in Advertising Discourse. Shanghai, China: Shanghai Foreign Language Education Press.

Hyland, K. (2000). Disciplinary Discourses: Social Interactions in Academic Writing. London: Longman.

Leech, G. N. (1966). English in Advertising. London: Longman.

Li, Z. Z. (2004). Appraisal Theory: Applications and Problems in Discourse Analysis. Foreign Languages Research, 5, 1-6.

Martin, J. R., \& David Rose. (2003). Working with Discourse - meaning beyond the clause. London: Continuum.

Martin, J. R., \& White, P. R. R. (2005). The Language of Evaluation: APPRAISAL, 38. London: Palgrave.

Painter, C. (2003). Developing attitude: An ontogenetic perspective on appraisal, Text, 23(2), 183-209. $\mathrm{http}: / / \mathrm{dx}$. doi.org/10.1515/text.2003.008

Peng, X. W. (2000). A Comprehensive Comparison between English and Chinese Texts. Shanghai, China: Shanghai Foreign Language Education Press.

Rothery, J., \& M. Stenglin. (2000). Interpreting Literature: the Role of Appraisal. In L. Unsworth (ed.), Researching Language in Schools and Communities: Functional Linguistic Perspectives. London: Cassell.

Veel. R. (1998). The Greening of School Science: Ecogenesis in Secondary Classrooms. In J. R. Martin \& R. Veel (eds.), Reading Science: Critical Functional Perspectives on Discourses of Science. London: Routledge.

Wang, Z. Z. (2001). APPRAISAL Systems and Their Operation: A New Development in the Systemic Functional Linguistics. Journal of Foreign Languages, 6, 13-20.

White, P. R. R. (1998). Telling Media Tales: the News Story as Rhetoric. Unpublished Ph.D article, University of Sydney, Sydney. 
White, P. R. R., \& Martin et al. (2001). An Introduction Tour through Appraisal Theory. Retrieved from www.grammatics.com/appraisal

White, P. R. R. (2003). Attitude and Arguability: Appraisal and the Linguistics of Solidarity. Text-Special Edition on: Appraisal.

Zhang, D. L. (1998). Functional Stylistic Theory. Jinan, China: Shandong Education Press. 